\title{
Analisis Kemampuan Komunikasi Matematika Dalam Menyelesaikan Masalah Pada Pokok Bahasan Sistem Persamaan Linier Dua Variabel Siswa Kelas VIII-C SMP Nuris Jember (An Analysis of Mathemathic Communication Skill in Solving Problems Linear Equation System of Two Variables Students Class VIII-C SMP Nuris Jember)
}

\author{
Zainul Arifin, Dinawati Trapsilasiwi, Arif Fatahillah \\ Jln. Kalimantan 37, Jember 68121 \\ E-mail:dinawati.fkip@unej.ac.id
}

Program Studi Pendidikan Matematika, Jurusan Pendidikan MIPA, FKIP, Universitas Jember

\begin{abstract}
Abstrak
Penelitian ini merupakan penelitian deskriptif yang bertujuan untuk menganalisis tingkat kemampuan komunikasi matematika siswa kelas VIII-C SMP Nuris Jember. Pengambilan data dilakukan menggunakan tes tulis dan lisan kepada 9 siswa. Pengambilan subjek diperoleh dari nilai ulangan harian matematika pokok bahasan sistem persamaan linier dua variabel. Dari nilai ulangan harian pokok bahasan sistem persamaan linier dikelompokan menjadi 3 tingkatan yaitu tingkat kemampuan matematika tinggi, sedang, dan rendah. Dari hasil analisis, diperoleh kesimpulan bahwa terdapat 2 siswa mampu memenuhi indikator pertama yaitu menuliskan penyelesaian masalah, 5 siswa mampu memenuhi indikator yang kedua yaitu mengubah masalah ke kalimat matematika, 4 siswa mampu memenuhi indikator yang ketiga yaitu perhitungan matematika, dan 5 siswa mampu memenuhi indikator yang keempat yaitu penggunaan simbol matematika. Siswa yang memiliki kemampuan komunikasi matematika sangat baik sudah mampu memenuhi keempat indikator, siswa yang memiliki kemampuan komunikasi matematika baik mampu memenuhi tiga indikator, sedangkan siswa yang memiliki kemampuan komunikasi matematika cukup hanya mampu memenuhi dua indikator meskipun masih ada kesalahan, siswa yang memiliki kemampuan komunikasi matematika kurang tidak mampu memenuhi keempat indikator kemampuan komunikasi matematika. Sehingga dari 3 siswa yang berkemampuan matematika tinggi terdapat 2 siswa berada pada tingkat kemampuan komunikasi matematika sangat baik dan 1 siswa berada pada kemampuan komunikasi matematika cukup, sedangkan untuk 3 siswa yang berkemampuan matematika sedang, ketiga siswa berada pada kemampuan komunikasi matematika baik, dan 3 siswa yang berkemampuan matematika rendah terdapat 2 siswa berada pada tingkat kemampuan komunikasi matematika cukup dan 1 siswa berada pada kemampuan komunikasi matematika kurang.
\end{abstract}

Kata Kunci: komunikasi matematika, kemampuan matematika.

\section{Abstract}

This research is a descriptive qualitative study aimed to analyze the level of mathemathic communication skill students class VIII-C at SMP Nuris Jember. The data was collected by using a written test and an oral test to 9 students. Subject retrieval obtained from the value of the daily tests of mathematics subject linear equation system of two variables. From the score of linear equations system daily tests, it was grouped into three levels, namely a high, medium, and low level of mathematical skill. From the analysis, it was concluded that there are two students who were able to meet the first indicator; write problem-solving, five students were able to meet the second indicator; change the problem into mathematics sentence, four students were able to meet the third indicators; mathematical calculations, and five students were able to meet the fourth indicators; use the mathematical symbols. Students who have a very good mathematical communication skills have been able to meet the four indicators, students who have the better communication skills of mathematics able to meet the three indicators, while students who have sufficient enough mathematical communication skills cover two indicators although there was still a mistake, who has less mathematical communication skills was unable to meet the four indicators of mathematical communication skills. So from three students that were capable of mathematical high there are two students who were on the level of very good mathematical communication skills and one of the students were on enough mathematical communication skills, while for the three students who are capable of mathematical being, the three students were both on mathematical communication skills, and 3 students enabled low mathematics there are two students who were on the level of enough mathematical communication skills and one student was at less mathematical communication skills.

Keywords : mathematical communication, mathematical skill

\section{Pendahuluan}

Pada era globalisasi saat ini, ilmu pengetahuan dan teknologi semakin maju dan berkembang seiring dengan kemajuan zaman. Salah satunya yaitu pendidikan, pendidikan memegang peranan penting terhadap perkembangan dan kemajuan dari suatu bangsa. Pendidikan 
yang maju dan berkualitas akan menciptakan sumber daya manusia yang berkualitas yang berguna dalam memajukan suatu bangsa.

Matematika merupakan salah satu ilmu pendidikan yang mempunyai peranan penting dalam kehidupan sehari-hari matematika sebagai bahasa simbol mengandung makna bahwa matematika bersifat universal dan dapat dipahami oleh setiap orang kapan dan di mana saja. Melalui mata pelajaran matematika, aljabar mulai diperkenalkan kepada siswa ditingkat Sekolah Menengah Pertama (SMP) [3]. Setiap simbol mempunyai arti yang jelas, dan disepakati secara bersama oleh semua orang [5].

Komunikasi merupakan bagian penting dalam setiap kegiatan manusia. Setiap saat orang melakukan kegiatan komunikasi. Untuk dapat berkomunikasi secara baik, orang memerlukan bahasa. Matematika merupakan salah satu bahasa yang juga dapat digunakan dalam berkomunikasi [1].

Pada kenyataannya, beberapa praktek di lapangan menunjukkan bahwa guru yang lebih aktif daripada siswa sehingga pembelajaran matematika dirasakan masih kurang memberikan kesempatan kepada siswa untuk mengembangkan kemampuan komunikasi matematika. Akibatnya siswa sering kali malu atau ragu untuk mengemukakan pendapatnya kepada siswa lain atau guru. Rasa malu ini menghambat dalam mengembangkan kemampuan komunikasi matematika dan pada akhirnya siswa juga ragu untuk mengungkapkan ide/gagasan dalam bentuk tulisan.

Dalam pembelajaran matematika seorang siswa yang sudah mempunyai kemampuan pemahaman matematik dituntut juga untuk bisa mengkomunikasikannya, agar pemahaman tersebut bisa dimengerti orang lain. Dengan mengkomunikasikan ide matematiknya pada orang lain seorang siswa dapat meningkatkan pemahaman matematiknya .

Ada 2 alasan penting yang menjadikan komunikasi perlu menjadi fokus perhatian dalam pembelajaran matematika yaitu (1) mathematics as language; matematika tidak hanya sekedar alat bantu berpikir (a tool to aid thinking), untuk menemukan pola, atau menyelesaikan masalah namun matematika juga "an invaluable tool for communicating a variety of ideas clearly, precisely, and succintly," dan (2) mathematics learning as social activity; sebagai aktivitas sosial dalam pembelajaran matematika, seperti komunikasi antar siswa dan komunikasi antara guru dan siswa [6].

Salah satu materi di kelas VIII adalah materi Sistem Persamaan Linier Dua Variabel. Materi ini berkaitan dengan kehidupan sehari-hari dan diharapkan siswa mampu mengkomunikasikannya. Namun, menurut hasil wawancara dengan salah satu guru matematika di SMP Nuris Jember, diketahui bahwa tingkat kemampuan komunikasi matematika siswa kelas VIII-C sangat beragam, maksudnya ada yang memiliki kemampuan komunikasi matematika sangat baik, ada yang memiliki kemampuan komunikasi matematika baik, ada yang memiliki kemampuan komunikasi matematika cukup dan ada yang memiliki kemampuan komunikasi matematika kurang. Permasalahan dalam penelitian ini adalah bagaimana tingkat kemampuan komunikasi matematika siswa kelas VIII-C SMP Nuris Jember.

\section{Metode Penelitian}

Jenis penelitian ini adalah penelitian deskriptif. Dengan demikian dalam penelitian ini akan dikumpulkan data rangka menjawab pertanyaan yang ada pada waktu penelitian. Selanjutnya menganalisis hasil dari tes yang dilakukan. Daerah penelitian adalah di SMP Nuris Jember.

Tahap pendahuluan pada penelitian ini yakni melakukan studi pendahuluan dan menyusun rancangan penelitian, Tahap penentuan daerah yaitu dengan metode purposive area yaitu menentukan daerah dengan sengaja berdasarkan beberapa pertimbangan. Tahap penentuan subjek yaitu seluruh siswa dalam satu kelas. Selanjutnya melihat hasil ulangan harian pada pokok bahasan sistem persamaan linier dua variabel, setelah itu mengambil 9 siswa yang akan dijadikan subjek penelitian. Tahap selanjutnya adalah pembuatan instrumen, intrumen yang digunakan antara lain instrumen tes kemampuan komunikasi matematika (tulis dan lisan) serta pedoman wawancara. Kedua instrumen tersebut dipergunakan untuk mengetahui bagaimana tingkat kemampuan komunikasi matematika siswa. Tentunya sebelum dipergunakan dilakukan validasi terlebih dahulu kepada 2 validator dosen matematika FKIP Universitas Jember. Setelah hasil validasi dianalisis dan dapat dikatakan valid barulah instrumen tersebut bisa diujicobakan dan dapat memulai pengumpulan data. Selanjutnya apabila keseluruhan data telah terkumpul dilakukan penganalisisan, guna menarik kesimpulan untuk menjawab rumusan masalah.

Instrumen yang digunakan dalam penelitian ini diantara lain yaitu peneliti sendiri, soal tes kemampuan komunikasi matematika, rubrik penilaian dan pedoman wawancara. Selain itu juga dibuat instrumen lembar validasi guna memberikan nilai pada instrumen yang telah dibuat. Sedangakan metode pengumpulan data yang digunakan dalam penelitian ini adalah metode dokumentasi berupa hasil nilai ulangan harian siswa pokok bahasan sistem persamaan linier dua variabel.

Dalam penelitian ini akan dianalisis tentang bagaimana tingkat kemampuan komunikasi matematika siswa pokok bahasan sistem persamaan linier dua variabel.

\section{Hasil Penelitian}

Adapun data yang diperoleh dari 9 siswa selaku subjek penelitian adalah sebagai berikut.

1. S01 adalah siswa yang memiliki kemampuan matematika tinggi pada materi Sistem Persamaan Linier Dua Variabel. Berdasarkan hasil tes tulis dan tes lisan kemampuan komunikasi matematika, siswa ini termasuk dalam siswa yang memiliki kemampuan komunikasi matematika sangat baik. Skor yang diperoleh dari tes tulis dan tes lisan adalah 88,83 . Ada 4 indikator kemampuan komunikasi matematika yaitu menyelesaikan masalah, mengubah masalah ke kalimat matematika, perhitungan matematika, dan penggunaan simbol matematika. Dari keempat indikator kemampuan komunikasi matematika, siswa ini sudah mampu memenuhi keempat indikator tersebut baik 
secara tulis maupun secara lisan.

2. S02 adalah siswa yang memiliki kemampuan matematika tinggi pada materi Sistem Persamaan Linier Dua Variabel. Berdasarkan hasil tes tulis dan tes lisan kemampuan komunikasi matematika, siswa ini termasuk dalam siswa yang memiliki kemampuan komunikasi matematika sangat baik. Skor yang diperoleh dari tes tulis dan tes lisan adalah 89,24. Ada 4 indikator kemampuan komunikasi matematika yaitu menyelesaikan masalah, mengubah masalah ke kalimat matematika, perhitungan matematika, dan penggunaan simbol matematika. Dari keempat indikator kemampuan komunikasi matematika, siswa ini sudah mampu memenuhi keempat indikator tersebut baik secara tulis maupun secara lisan.

3. S03 adalah siswa yang memiliki kemampuan matematika tinggi pada materi Sistem Persamaan Linier Dua Variabel. Berdasarkan hasil tes tulis dan tes lisan kemampuan komunikasi matematika, siswa ini termasuk dalam siswa yang memiliki kemampuan komunikasi matematika baik. Skor yang diperoleh dari tes tulis dan tes lisan adalah 70,20. Ada 4 indikator kemampuan komunikasi matematika yaitu menyelesaikan masalah, mengubah masalah ke kalimat matematika, perhitungan matematika, dan penggunaan simbol matematika. Dari keempat indikator kemampuan komunikasi matematika, siswa ini hanya mampu memenuhi tiga indikator tersebut baik secara tulis maupun secara lisan.

4. S04 adalah siswa yang memiliki kemampuan matematika sedang pada materi Sistem Persamaan Linier Dua Variabel. Berdasarkan hasil tes tulis dan tes lisan kemampuan komunikasi matematika, siswa ini termasuk dalam siswa yang memiliki kemampuan komunikasi matematika baik. Skor yang diperoleh dari tes tulis dan tes lisan adalah 72,17. Ada 4 indikator kemampuan komunikasi matematika yaitu menyelesaikan masalah, mengubah masalah ke kalimat matematika, perhitungan matematika, dan penggunaan simbol matematika. Dari keempat indikator kemampuan komunikasi matematika, siswa ini hanya mampu memenuhi tiga indikator tersebut baik secara tulis maupun secara lisan.

5. S05 adalah siswa yang memiliki kemampuan matematika sedang pada materi Sistem Persamaan Linier Dua Variabel. Berdasarkan hasil tes tulis dan tes lisan kemampuan komunikasi matematika, siswa ini termasuk dalam siswa yang memiliki kemampuan komunikasi matematika baik. Skor yang diperoleh dari tes tulis dan tes lisan adalah 75,35. Ada 4 indikator kemampuan komunikasi matematika yaitu menyelesaikan masalah, mengubah masalah ke kalimat matematika, perhitungan matematika, dan penggunaan simbol matematika. Dari keempat indikator kemampuan komunikasi matematika, siswa ini hanya mampu memenuhi tiga indikator tersebut baik secara tulis maupun secara lisan.

6. S06 adalah siswa yang memiliki kemampuan matematika sedang pada materi Sistem Persamaan Linier Dua Variabel. Berdasarkan hasil tes tulis dan tes lisan kemampuan komunikasi matematika, siswa ini termasuk dalam siswa yang memiliki kemampuan komunikasi matematika cukup. Skor yang diperoleh dari tes tulis dan tes lisan adalah 50,52. Ada 4 indikator kemampuan komunikasi matematika yaitu menyelesaikan masalah, mengubah masalah ke kalimat matematika, perhitungan matematika, dan penggunaan simbol matematika. Dari keempat indikator kemampuan komunikasi matematika, siswa ini hanya mampu memenuhi dua indikator tersebut baik secara tulis maupun secara lisan.

7. S07 adalah siswa yang memiliki kemampuan matematika rendah pada materi Sistem Persamaan Linier Dua Variabel. Berdasarkan hasil tes tulis dan tes lisan kemampuan komunikasi matematika, siswa ini termasuk dalam siswa yang memiliki kemampuan komunikasi matematika cukup. Skor yang diperoleh dari tes tulis dan tes lisan adalah 50,18. Ada 4 indikator kemampuan komunikasi matematika yaitu menyelesaikan masalah, mengubah masalah ke kalimat matematika, perhitungan matematika, dan penggunaan simbol matematika. Dari keempat indikator kemampuan komunikasi matematika, siswa ini hanya mampu memenuhi dua indikator tersebut baik secara tulis maupun secara lisan.

8. S08 adalah siswa yang memiliki kemampuan matematika rendah pada materi Sistem Persamaan Linier Dua Variabel. Berdasarkan hasil tes tulis dan tes lisan kemampuan komunikasi matematika, siswa ini termasuk dalam siswa yang memiliki kemampuan komunikasi matematika kurang. Skor yang diperoleh dari tes tulis dan tes lisan adalah 28,99. Ada 4 indikator kemampuan komunikasi matematika yaitu menyelesaikan masalah, mengubah masalah ke kalimat matematika, perhitungan matematika, dan penggunaan simbol matematika. Dari keempat indikator kemampuan komunikasi matematika, siswa ini tidak mampu memenuhi keempat indikator.

9. S09 adalah siswa yang memiliki kemampuan matematika rendah pada materi Sistem Persamaan Linier Dua Variabel. Berdasarkan hasil tes tulis dan tes lisan kemampuan komunikasi matematika, siswa ini termasuk dalam siswa yang memiliki kemampuan komunikasi matematika kurang. Skor yang diperoleh dari tes tulis dan tes lisan adalah 27,37. Ada 4 indikator kemampuan komunikasi matematika yaitu menyelesaikan masalah, mengubah masalah ke kalimat matematika, perhitungan matematika, dan penggunaan simbol matematika. Dari keempat indikator kemampuan komunikasi matematika, siswa ini tidak mampu memenuhi keempat indikator tersebut baik secara tulis maupun secara lisan.

\section{Pembahasan}

Hasil analisis data kemampuan komunikasi matematika adalah sebagai berikut: Dari 9 subjek penelitian didapatkan 2 siswa mampu memenuhi indikator pertama yaitu menuliskan penyelesaian masalah, 5 siswa mampu memenuhi indikator yang kedua yaitu mengubah masalah ke kalimat matematika, 4 siswa mampu memenuhi indikator yang ketiga yaitu perhitungan matematika, dan 5 siswa mampu memenuhi indikator yang keempat yaitu penggunaan simbol matematika.

Siswa berkemampuan matematika tinggi termasuk ke dalam siswa yang memiliki kemampuan komunikasi matematika sangat baik artinya siswa tersebut sudah mampu memenuhi keempat indikator, siswa berkemampuan 
matematika sedang termasuk ke dalam siswa yang memiliki kemampuan komunikasi matematika cukup artinya siswa tersebut mampu memenuhi dua indikator, sedangkan siswa berkemampuan matematika rendah termasuk ke dalam siswa yang memiliki kemampuan komunikasi matematika kurang artinya siswa tersebut hanya mampu memenuhi satu indikator meskipun masih ada kesalahan.

Berdasarkan analisis yang telah dilakukan terdapat perbedaan antara siswa yang kemampuan matematika tinggi, sedang, serta rendah, dan perbedaan ini mengisyaratkan bahwa terdapat aspek kemampuan komunikasi matematika siswa baik secara tulis dan lisan yang memisahkan antar siswa dengan kemampuan matematika yang berbeda. Sehingga dapat disimpulkan bahwa semakin rendah tingkat kemampuan matematika siswa maka kemampuan komunikasi matematika siswa juga semakin berkurang. Hasil penelitian ini kurang sempurna, karena rubrik penelitian dibuat sendiri oleh peneliti, mungkin pada penelitian yang selanjutnya agar di sempurnakan. Hasil tersebut selaras dengan penelitian yang menyatakan bahwa terdapat hubungan signifikan antara kemampuan matematika dan kemampuan komunikasi matematika siswa sehingga semakin tinggi kemampuan matematika siswa maka kemampuan komunikasi matematikanya semakin tinggi pula [4]. Hasil tersebut juga selaras dengan penelitian yang menyatakan bahwa penerapan metode accelerated learning berhasil meningkatkan kemampuan komunikasi matematis siswa [2].

\section{Kesimpulan dan Saran}

a) Subjek berkemampuan matematika tinggi

Dari 3 siswa yang memiliki kemampuan matematika tinggi, 2 siswa berada pada tingkat kemampuan komunikasi matematika sangat baik dan 1 siswa berada pada kemampuan komunikasi matematika cukup. Siswa yang memiliki kemampuan komunikasi sangat baik sudah mampu memenuhi keempat indikator, sedangkan siswa yang memiliki kemampuan komunikasi matematika cukup hanya mampu memenuhi 2 indikator kemampuan komunikasi matematika.

b) Subjek kemampuan matematika sedang

Dari 3 siswa yang memiliki kemampuan matematika sedang, ketiga siswa berada pada kemampuan komunikasi matematika baik. Siswa yang memiliki kemampuan komunikasi matematika baik sudah mampu memenuhi tiga indikator kemampuan komunikasi matematika.

c) Subjek kemampuan matematika rendah

Dari 3 siswa yang memiliki kemampuan matematika rendah, 2 siswa berada pada tingkat kemampuan komunikasi matematika cukup dan 1 siswa berada pada kemampuan komunikasi matematika kurang. Siswa yang memiliki kemampuan komunikasi cukup mampu memenuhi dua indikator meskipun masih ada kesalahan, sedangkan siswa yang memiliki kemampuan komunikasi kurang hanya mampu memenuhi satu indikator meskipun masih ada kesalahan.

Berdasarkan data di atas, dapat disimpulkan bahwa terdapat 2 siswa yang memiliki kemampuan komunikasi matematika sangat baik, 3 siswa memiliki kemampuan komunikasi matematika baik, 2 siswa memiliki kemampuan

komunikasi matematika cukup, dan 2 siswa memiliki kemampuan komunikasi matematika kurang.

Adapun beberapa saran yang bisa diberikan yakni sebagai berikut:

1) bagi guru, diharapkan dapat melatih siswa dalam menyampaikan apa yang dipahami sehingga kemampuan komunikasi siswa semakin terasah ;

2) bagi guru, diharapkan memberikan latihan soal yang mencakup kehidupan sehari-hari dan memerlukan kemampuan komunikasi matematika dalam menyelesaikannya;

3) bagi sekolah, hasil penelitian ini bisa dijadikan salah satu pertimbangan untuk mengetahui kemampuan komunikasi matematika siswa dan meningkatkan kemampuannya;

4) bagi siswa, dibiasakan untuk bisa menyampaikan apa yang dipahami sehingga kemampuan komunikasi matematika semakin meningkat;

5) bagi peneliti lain, dapat dijadikan rujukan dalam melakukan penelitian yang sejenis.

\section{Ucapan Terima Kasih}

Penulis mengucapkan terimakasih kepada SMP Nuris Jember atas kesediannya memberikan bantuan dalam penyelenggaraan penelitian ini. Penulis juga mengucapkan banyak terimakasih kepada dosen pembimbing 1 dan dosen pembimbing 2 yang telah dengan sabar membimbing peneliti

dalam melaksanakan penelitian hingga akhir.

\section{Daftar Pustaka}

1] Armianti. 2009. Komunikasi Matematika dan Kecerdasan Emosional. Jurnal UPI

[2] Damayanti, Dina. 2012. Penerapan Metode Accelerated Learning dalam Pembelajaran Matematika untuk Meningkatkan Kemampuan Komunikasi Matematis Siswa SMP. Bandung: tidak diterbitkan

3] Limardani, G. Analisis Kesulitan Siswa dalam menyelesaikan Soal Aljabar Berdasarkan Teori Pemahaman Skemp Pada Siswa Kelas VIIID SMP Negeri 4 Jember. Jember : Repository UNEJ

[4] Putri, Cintya. 2015. Analisis Kemampuan Komunikasi Matematis Siswa Kelas VIII SMP pada Model Pembelajaran TSTS dengan Pendekatan Scientific. Jurnal Universitas Negeri Semarang.

[5] Sumarmo, U. 2000. Implementasi Kurikulum 1994 Pada Sekolah Dasar dan Sekolah Menengah. Laporan Penelitian Bandung: FMIPA IKIP Bandung.

[6] Umar, Wahid. 2012. Membangun Kemampuan Komunikasi Matematis Dalam Pembelajaran Matematika. Jurnal STKIP Siliwangi Bandung. 